$\begin{array}{ll}\text { Research Square } & \begin{array}{l}\text { Preprints are preliminary reports that have not undergone peer review. } \\ \text { They should not be considered conclusive, used to inform clinical practice, } \\ \text { or referenced by the media as validated information. }\end{array}\end{array}$

\title{
Soil microbial communities, soil nutrition, and seedling growth of a Chinese fir (Cunninghamia lanceolata (Lamb.) Hook.) plantation in response to three weed control methods
}

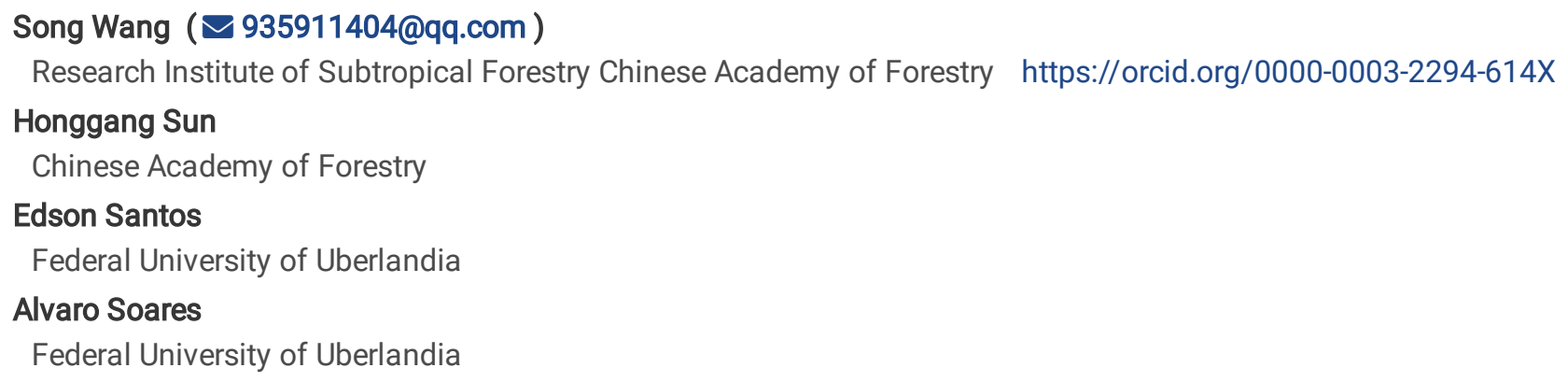

\section{Research Article}

Keywords: Chinese fir, weeding, soil bacterial community, soil properties, leaves nutrition

Posted Date: February 1st, 2022

DOI: https://doi.org/10.21203/rs.3.rs-1242443/v1

License: (c) (1) This work is licensed under a Creative Commons Attribution 4.0 International License. Read Full License 


\section{Abstract}

Background and aims Competitive vegetation in forest stands influence seedling growth by changing soil nutrient availability. However, studies on the effects of different weed control methods on seedling growth of Chinese fir (Cunninghamia lanceolata (Lamb.) Hook.) are rare.

Methods We applied three weed control methods, comprising artificial sickle weeding (ASW), woody disc weeding (WDW), and nonwoven cloth weeding (nWCW), to explore their effect on growth of Chinese fir seedlings in a plantation in Jiangxi Province, China.

Results The weed control methods affected the shoot height and root-collar diameter of the seedlings. The contents of sugar, glucose, triglycerides, total cholesterol, and free fatty acids in newly developed leaves were increased after ASW and nWCW treatment, and were consistent with the expression of genes associated with glucokinase, sucrose phosphate synthase, and sucrose synthase. Weeding method influenced soil properties, including $\mathrm{pH}$, moisture, total nitrogen $(\mathrm{N})$, ammonium- $\mathrm{N}$, nitrate- $\mathrm{N}$, total phosphorus, available phosphorus, and dissolved organic carbon contents. Moisture content was the main factor that influenced the soil bacterial community and leaf nutrition. High-throughput sequencing of the bacterial 16S rRNA gene revealed that the weeding methods affected bacterial community structure. Specifically, compared with ASW and nWCW, WDW contributed to lower soil bacterial diversity, simpler bacterial interaction, and increase in pathogenic bacteria potential.

Conclusions The weeding methods differ in influence on soil bacterial community structure, soil properties, and plant growth, which are potentially useful as indices of biomass productivity to improve the growth of Chinese fir seedlings.

\section{Introduction}

Weeds in tree plantations reduce the leaching of nutrients, improve microclimates, reduce the risks of wind damage and water erosion, and improve biodiversity. However, it is important to strike a balance between protection of soil and water properties and reduction of weed competition with trees, because these interactions restrict the growth of tree seedlings and may cause their death (Zimdahl et al., 2007; Cierjacks et al., 2016; Peachey et al., 2017; dos Santos et al., 2019). Weeds interfere with tree growth by competing for nutrients, water, space, light, and oxygen, and may harbor pests and pathogens. Hence, effective weed management in forest nurseries are extremely important for initial conifer seedling survival and in the first 3 years after transplanting (during the establishment period) in the field (Knowe et al., 1995; Schneider et al., 1998; Harper et al., 2005).

Application of herbicides is a common and effective strategy for weed control in plantation forestry (Newton, 2006), but potentially harmful consequences are profound and long-lasting. During the establishment phase, in particular, young trees are sensitive to chemical herbicides. Many herbicides may cause severe phytotoxic injury to trees, including stunted growth, burning and abscission of needles, chlorosis, or death of the tree. Repeated applications of the same herbicide may result in development of herbicide resistance among weed species (Hill, 2018). In addition to their effects on plants, herbicides may interfere with enzymatic activities, biochemical processes, microorganism diversity, and microbial functions in the soil (Sannino et al., 2001; Kinney et al., 2005; Mahia et al., 2008; Liu et al., 2020b). For example, mesosulfuron-methyl influences the biodegradability potential and nitrogen (N) transformation in the soil, decreases bacterial and fungal abundance, and alters microbial diversity and community composition (Du et al., 2021). Repeated application of atrazine alters the soil microbial community structure (Seghers et al., 2003). Atrazine and metolachlor alter the species biodiversity of actinomycetes and bacteria in the soil (Seghers et al., 2003; Liu et al., 2020b). Glyphosate may inhibit the growth and activity of soil biota, and has toxic effects on mycorrhizal fungi (Santos et al., 1995). Many changes in the diversity and composition of the beneficial microbial community can be unfavorable to plant growth and development by reducing nutrient availability or by increasing disease incidence. Therefore, effective nonchemical weed-control strategies are required urgently.

Mechanical or manual control methods, such as mowing, may assist in preventing the development of herbicide-tolerant weed species, reduce the number of seeds produced by the weeds, and significantly reduce weed competition with the trees when implemented at the optimal time point prior to weed seed development. Certain artificial mowing methods promote the growth of trees, such as loblolly pine (Pinus taeda L.), slash pine (Pinus elliottii Engelm. var. elliottii), and improve forest biomass, productivity, and tree survival (Vogel et al., 2010; Hamberg et al., 2011). However, large mowing equipment increases the risk of damage to the trees, and exclusive dependence on a hand weeding method to control weeds is labor intensive, expensive, and time consuming. A number of alternative unconventional weed management strategies, including harvest weeds control, seed predation, mulching, development of herbicide-resistant crops, and bioherbicides, may be viable, feasible, and efficient (Bajwa et al., 2017). Nonchemical 
methods of vegetation control, such as mechanical site preparation, in some studies are reported to be as effective as repeated herbicide treatments (Nilsson and Örlander, 1999).

Chinese fir (Cunninghamia lanceolata), among the most common coniferous species in subtropical regions of China, is a fastgrowing native tree that has been planted for timber production for more than 1000 years (Ma et al., 2007). The species grows in diverse habitats ranging from hills to high mountains, from fertile soils to infertile sites, and from small disconnected fragments of habitat to large continuous areas. Recently, with the increasing national demand for wood products because of population expansion and economic development, the area of Chinese fir plantations has expanded rapidly. In some regions, the rotation period of plantations has been shortened to 17 years (Bi et al., 2007). However, continuous silvicultural activities are responsible for degradation of soil fertility, decrease in standing biomass, and reduced primary productivity of Chinese fir plantations (Tian et al., 2011). Given that weeds can affect tree growth, the development of measures to control weeds and maintain soil fertility to promote the growth of Chinese fir plantations are important. In this study, we applied three methods to suppress the growth of competitive weeds around Chinese fir seedlings, and compared the effects of the weeding methods on the soil microbial community, soil properties, and growth of Chinese fir seedlings. The objective was to evaluate the feasibility of nonchemical weed control strategies in Chinese fir production and the surrounding environment, where microbial communities and soil nutrition are directly influenced by mowing and mulching. Such strategies are important for implementation of sustainable forest nursery and forestry practices.

\section{Materials And Methods}

Study area and sample collection

The experiment was established in Fengshushan Forestry Farm $\left(29^{\circ} 17^{\prime} \mathrm{N}, 117^{\circ} 22^{\prime} \mathrm{E}\right)$, Jiangxi Province, China. The study site was located in a Chinese fir (Cunninghamia lanceolata (Lamb.) Hook.) plantation at an elevation of $43.0 \mathrm{~m}$. The area experiences a typical long warm summer and short cool winter. The annual mean temperature, and mean temperatures in January and July are 17.1, 4.6, and $28.7^{\circ} \mathrm{C}$, respectively. The average length of the growing season is 264 days and mean annual precipitation is $1805 \mathrm{~mm}$. The average depth of the krasnozem soil is $50 \mathrm{~cm}$.

A randomized complete-block experimental design was used. Twenty-one Chinese fir seedlings per weed control method, with $2.0 \mathrm{~m} \times$ $2.0 \mathrm{~m}$ planting density, were randomly selected for growth measurement on January 2019. Shoot height and root-collar diameter of the Chinese fir seedlings with $20 \mathrm{~cm}$ and $0.5 \mathrm{~cm}$ were selected as the targets of cultivation. One year after the three weeding treatments were performed, shoot height and root-collar diameter were recorded on 15 January 2020. Twenty-one newly developed leaves from the lateral branches of the Chinese fir seedlings were sampled per treatment for physiological and gene expression analyses. An S-shaped sampling method was used to collect soil cores with a soil borer at $10 \mathrm{~cm}$ depths for each treatment. The soil and leaf samples were sealed in sterile plastic bags and transported on dry ice to the laboratory within $24 \mathrm{~h}$, where the samples were quickly frozen using liquid nitrogen and stored at $-80^{\circ} \mathrm{C}$ until subsequent analysis. The soil samples were mixed thoroughly, and then passed through a $2 \mathrm{~mm}$ sieve and divided into two portions. One portion was used to measure soil physicochemical properties.

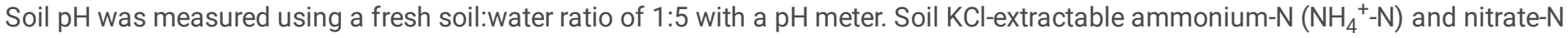
$\left(\mathrm{NO}_{3}{ }^{-} \mathrm{N}\right)$ were extracted using a mixture of fresh soil and $2 \mathrm{M} \mathrm{KCl}(1: 5, \mathrm{w} / \mathrm{v})$ with shaking at $200 \mathrm{rpm}$ for $1 \mathrm{~h}$, and quantified using a segmented flow analyzer (SANCC, Skalar, Breda, The Netherlands). Soil moisture content was determined by oven-drying the samples at $105^{\circ} \mathrm{C}$ (Chinese Industry Standard LY/T 1213-1999). Dissolved organic carbon (DOC) was extracted with $0.5 \mathrm{M} \mathrm{K}_{2} \mathrm{SO}_{4}$ and the content determined using a total organic carbon analyzer (Multi N/C 3000; Analytik, Jena, Germany; Watkins et al., 1987). Total nitrogen (TN) and total phosphorus (TP) were analyzed using semi-macro Kjeldahl digestion and the molybdenum-antimony colorimetric method followed by $\mathrm{H}_{2} \mathrm{SO}_{4}$ digestion, respectively (Allen, 1974). Available phosphorus (AP) was extracted using sodium bicarbonate and analyzed using the molybdenum-blue colorimetric method after extraction with diluted $\mathrm{H}_{2} \mathrm{SO}_{4}-\mathrm{HCl}$ (Chinese Industry Standard LY/T 1232-2015).

Competitive weed control methods

The three weeding methods used in this study were artificial sickle weeding (ASW), woody disc weeding (WDW), and nonwoven cloth weeding (nWCW) (Fig. 1). Artificial sickle weeding involved cutting down all herbs, shrubs, lianes, and nontarget tree species in the experimental plots with sickles twice a year (in mid-April and mid-September of 2019). To maintain the soil fertility and nourish the 
seedlings of Chinese fir, cut weeds were leaved on site to decay into organic maters. Woody disc weeding comprised generating a mixture mainly of sawdust, bamboo shavings, rice straw, and tree bark through high mechanical pressure, which was painted with a waterproof coating and used to cover the plots. A gap ( $5 \mathrm{~cm}$ diameter) was left in the center of each disc (40 cm diameter and $5 \mathrm{~mm}$ thickness). This woody mulch was applied around the base of each seedling after planting with the aim of inhibiting the growth of competitive weeds by blocking the available light. For the nWCW treatment, nonwoven black cloth prepared from recycled cotton $(2 \mathrm{~m}$ width and $0.5 \mathrm{~mm}$ thickness) was used. The cloth was porous to allow water to easily permeate through it, but penetration of sunlight was absolutely impeded and the soil temperature was effectively maintained. The nonwoven cloth was spread on the soil surface between rows of seedlings in the experimental plots to obstruct access to light by competitive weeds. For the WDW and nWCW treatments, all plants within at least a $1 \mathrm{~m}^{2}$ radius of the seedling were artificially uprooted.

\section{Soil DNA extraction and high-throughput 16S rRNA gene sequencing}

Total bacterial DNA was extracted from soil samples using the PowerSoil DNA Isolation Kit (MO BIO Laboratories). The DNA quality and quantity were assessed with an Agilent 2100 Bioanalyzer (Agilent Technologies, Palo Alto, CA, USA) and Qubit 2.0 Fluorometer (Life Technologies, Carlsbad, CA, USA). The purified DNA was stored at $-80^{\circ} \mathrm{C}$ until further processing. The V3-V4 region of the bacterial 16S rRNA gene was amplified using the forward primer 338F (5'-ACTCCTACGGGAGGCAGCA-3') and reverse primer 806R (5'GGACTACHVGGGTWTCTAAT-3') combined with adapter sequences and barcode sequences. Each PCR amplification was performed in a $50 \mu \mathrm{L}$ volume containing $10 \mu \mathrm{L}$ buffer, $0.2 \mu \mathrm{L}$ of Q5 High-Fidelity DNA Polymerase, $10 \mu \mathrm{L}$ High GC Enhancer, $1 \mu \mathrm{L}$ dNTPs, $10 \mu \mathrm{M}$ of each primer, and $60 \mathrm{ng}$ template DNA. The following PCR program was used: initial denaturation at $95^{\circ} \mathrm{C}$ for 5 min, followed by 15 cycles at $95^{\circ} \mathrm{C}$ for $1 \mathrm{~min}, 50^{\circ} \mathrm{C}$ for $1 \mathrm{~min}$, and $72^{\circ} \mathrm{C}$ for $1 \mathrm{~min}$, with a final extension at $72^{\circ} \mathrm{C}$ for $7 \mathrm{~min}$. The PCR products from the firststep PCR were purified using VAHTS ${ }^{\text {TM }}$ DNA Clean Beads. A second-round PCR was then performed in a $40 \mu \mathrm{L}$ reaction volume that contained $20 \mu \mathrm{L}$ of $2 \times$ Phusion HF MM, $8 \mu \mathrm{L}$ ddH2O, $10 \mu \mathrm{M}$ of each primer, and $10 \mu \mathrm{L}$ first-step PCR products. The second-step PCR program comprised an initial denaturation at $98^{\circ} \mathrm{C}$ for $30 \mathrm{~s}$, followed by 10 cycles at $98^{\circ} \mathrm{C}$ for $10 \mathrm{~s}, 65^{\circ} \mathrm{C}$ for $30 \mathrm{~s}$, and $72^{\circ} \mathrm{C}$ for $30 \mathrm{~s}$, with a final extension at $72^{\circ} \mathrm{C}$ for 5 min. Finally, all PCR products were quantified using Quant-iT ${ }^{T M}$ dsDNA HS Reagent and pooled. High-throughput sequencing analysis of the bacterial rRNA genes in the purified, pooled sample was performed using an Illumina HiSeq 2500 platform (with $2 \times 250$ paired ends) by Biomarker Technologies Corporation (Beijing, China).

Chemical analyses

To determine the contents of sugars, glucose (GLU), triglycerides (TG), total cholesterol (TCH), and free fatty acids (FFAs), the sampled needles were defrosted and homogenized with nine volumes of pre-cooled phosphate-buffered solution, and then centrifuged at $3000 \times g$ at $4^{\circ} \mathrm{C}$ for $10 \mathrm{~min}$. The concentrations of sugars, GLU, TG, TCH, and FFA in the supernatant were determined using kits purchased from the Nanjing Jiancheng Institute of Biotechnology (Nanjing, China) in accordance with the manufacturer's instructions.

Expression of genes associated with energy metabolism in newly developed needles

Total RNA in the sampled needles was isolated with TRIzol Reagent (TaKaRa, Dalian, China) in accordance with the manufacturer's instructions. The PrimeScript II 1st Strand cDNA Synthesis Kit (TaKaRa) was used to perform reverse transcription. The RNA quantity and quality were assessed by determining the ratio of absorbance at 260 and $280 \mathrm{~nm}$ with a NanoDrop spectrophotometer (Thermo Fisher Scientific, Wilmington, DE, USA) and an Agilent 2100 Bioanalyzer (Agilent Technologies). First-strand cDNA was synthesized from I.0 $\mu \mathrm{g}$ total RNA using M-MLV reverse transcriptase (Invitrogen, Carlsbad, CA, USA). Quantitative RT-PCR (RT-qPCR) was performed using Premix Ex Taq ${ }^{\text {TM }}$ with SYBR Green (TaKaRa) and an ABI 7500 Fast Real-Time PCR System (Applied Biosystems, Carlsbad, CA, USA). The qPCR protocol was as follows: the thermocycle protocol for $30 \mathrm{~s}$ at $95^{\circ} \mathrm{C}$, followed by 40 cycles of denaturation at $95^{\circ} \mathrm{C}$ for $5 \mathrm{~s}$, annealing/extension at $60^{\circ} \mathrm{C}$ for $35 \mathrm{~s}$, and a final melting-curve analysis to monitor the purity of the PCR product. Primer sequences were designed and selected using Primer 5.0. The $2^{-\triangle \triangle C t}$ method was used to calculate the abundance of mRNA. Relative gene expression levels were standardized relative to the housekeeping gene GAPDH.

\section{Data analysis}

After the barcode and primer of the raw sequences were trimmed, sequence reads were spliced and filtered using FLASH v1.2.11 and Trimmomatic v0.33, respectively. Clean reads were clustered into operational taxonomic units (OTUs) at the threshold of $97 \%$ similarity after the chimeras of filtered reads were eliminated using UCHIME v8.1. Alpha diversity and beta diversity between the 
samples were analyzed with QIIME v1.9.1 (Caporaso et al., 2010). A species richness estimator (Chao 1), abundance-based coverage estimator (ACE) and diversity indices (Shannon and Simpson) were determined using Mothur (Schloss et al., 2009). The dissimilarity of microbial communities among samples was evaluated using principal coordinates analysis, and a permutational multivariate analysis of variance (PERMANOVA) was conducted, using a Bray-Curtis distance matrix calculated using the R package "vegan" and the permuted $P$-value was obtained with 10,000 permutations. The unweighted pair-group method with arithmetic means (UPGMA) was used to evaluate the similarity of the bacterial communities using beta-diversity data and QIIME v1.9.1.

Representative OTUs were taxonomically assigned using the RDP classifier v2.2 against the SILVA database (v115) (Wang et al., 2007). A linear discriminant analysis (LDA) effect size (LEfSe) analysis was performed online with the default parameters (minimum LDA score $(\log 10) \geq 4.0$ and 30 bootstrap iterations to identify the highly abundant bacteria that showed dimensional patterns among the three weeding methods (Segata et al., 2011). A nonparametric factorial Kruskal-Wallis rank-sum test accompanied by the unpaired Wilcoxon rank-sum test were used to identify the taxa with the greatest differences in relative abundance. The Kyoto Encyclopedia of Genes and Genomes (KEGG) metabolic pathways enriched among the soil bacteria were analyzed using Phylogenetic Investigation of Communities by Reconstruction of Unobserved States (PICRUSt) (http://huttenhower.sph.harvard.edu/galaxy/tool_runner?toll_id=PICRUSt_normalize). The relative frequencies of the function of overall KEGG Orthologs (KOs) associated with carbon metabolism, nitrogen metabolism, and the phosphorus cycle were analyzed using Dunn's paired test after the Kruskal-Wallis test. BugBase (https://bugbase.cs.umn.edu/) was used to predict organism-level microbiome phenotypes; the significance of differences in relative abundance of phenotypes between two groups was assessed by performing pairwise Mann-Whitney-Wilcoxon tests after the Kruskal-Wallis test. Co-occurrence networks of the soil microbial communities in the different weeding groups were generated based on significant correlations (Spearman's $\rho>0.8$ and $P<0.05$ ) and were visualized using Gephi software (https://gephi.org/). The Mantel test was performed to assess the correlation between soil properties and the top 10 bacteria at phylum level. Using CANOCO for Windows (v5.02), a canonical correspondence analysis (CCA) was performed to evaluate the soil property that best explained the variation in bacterial community structure.

For the soil properties data, the contents of organic nutrients in newly developed leaves, and the qPCR results, differences between groups were analyzed using Turkey's test after one-way analysis of variance (ANOVA) using SPSS 20.0 (IBM Corporation, Armonk, NY, USA). If data were non-normally distributed or the variances were unequal, the Kruskal-Wallis test and Dunn's test were applied for multiple comparisons. Results are expressed as the mean \pm standard error of the mean (SEM).

\section{Results}

Effects of the weed control method on soil properties

The three weeding methods differentially affected rhizosphere soil properties of the Chinese fir plantation (Table 1). The soil pH remarkably decreased in response to the WDW and nWCW treatments $(p<0.05)$. The soil moisture content was significantly higher under nWCW than that under WDW and was lowest in response to WDW $(p<0.05)$. The total $\mathrm{N} \mathrm{NH}_{4}{ }^{+}-\mathrm{N}$, and $\mathrm{NO}_{3}{ }^{-}-\mathrm{N}_{\text {contents were }}$ increased under WDW and nWCW compared with those under ASW $(p<0.05)$. The AP contents in the WDW and nWCW treatments were significantly lower than that under ASW $(p<0.05)$. The TP content was not significantly affected by weeding method $(p>0.05)$. The WDW and nWCW treatments significantly increased the DOC content compared with the ASW treatment $(p<0.05)$.

Table 1

Effect of three weed control methods on soil properties of a Chinese fir plantation

\begin{tabular}{|lllllllll|}
\hline Treatment & $\mathrm{pH}\left(\mathrm{H}_{2} \mathrm{O}\right)$ & $\mathrm{SM}(\%)$ & $\begin{array}{l}\mathrm{NH}_{4}{ }^{+}-\mathrm{N}(\mathrm{mg} \\
\left.\mathbf{k g}^{-1}\right)\end{array}$ & $\begin{array}{l}\mathrm{NO}_{3}{ }^{-}-\mathrm{N} \\
\left(\mathrm{mg} \mathrm{kg}^{-1}\right)\end{array}$ & $\mathrm{TN}(\mathrm{g} / \mathbf{k g})$ & $\begin{array}{l}\mathrm{AP}(\mathrm{mg} \\
\left.\mathbf{k g}^{-1}\right)\end{array}$ & $\begin{array}{l}\mathrm{TP}(\mathrm{g} \\
\left.\mathbf{k g}^{-1}\right)\end{array}$ & $\begin{array}{l}\mathrm{DOC}(\mathrm{mg} \\
\left.\mathbf{k g}^{-1}\right)\end{array}$ \\
\hline ASW & $4.39 \pm 0.05^{\mathrm{a}}$ & $0.53 \pm 0.12^{\mathrm{ab}}$ & $10.43 \pm 1.75^{\mathrm{b}}$ & $2.88 \pm 0.43^{\mathrm{b}}$ & $0.98 \pm 0.10^{\mathrm{c}}$ & $1.22 \pm 0.13^{\mathrm{a}}$ & $0.23 \pm 0.03$ & $47.59 \pm 5.81^{\mathrm{b}}$ \\
\hline WDW & $4.15 \pm 0.06^{\mathrm{b}}$ & $0.38 \pm 0.16^{\mathrm{b}}$ & $17.33 \pm 1.55^{\mathrm{a}}$ & $5.45 \pm 0.79^{\mathrm{a}}$ & $1.31 \pm 0.09^{\mathrm{a}}$ & $0.85 \pm 0.17^{\mathrm{b}}$ & $0.20 \pm 0.03$ & $54.74 \pm 7.07^{\mathrm{a}}$ \\
\hline nWCW & $4.21 \pm 0.09^{\mathrm{b}}$ & $0.60 \pm 0.11^{\mathrm{a}}$ & $15.45 \pm 2.82^{\mathrm{a}}$ & $6.95 \pm 0.60^{\mathrm{a}}$ & $1.12 \pm 0.06^{\mathrm{b}}$ & $0.94 \pm 0.09^{\mathrm{b}}$ & $0.21 \pm 0.02$ & $52.85 \pm 6.39^{\mathrm{ab}}$ \\
\hline
\end{tabular}

Data are the mean \pm standard error of the mean (SEM) $(n=7)$. Different lower-case letters within a column indicate a significant difference among weed control methods $(p<0.05)$. SM: Soil moisture; TN: total nitrogen; AP: available phosphorus; TP: total phosphorus; DOC: dissolved organic matter 
The shoot height and root-collar diameter of Chinese fir seedlings were measured to analyze the influence of weeding method on seedling growth and biomass. The shoot height in the nWCW treatment was significantly higher than that of the ASW and WDW groups (Fig. 2A). Similarly, the root-collar diameter was significantly higher under nWCW and showed no significant difference between the ASW and WDW treatments (Fig. 2B). These findings showed that growth of Chinese fir seedlings was superior in response to ASW and nWCW than that under WDW.

Composition of the soil microorganism community under the weed control methods

\section{Alpha diversity}

The soil bacterial communities of 21 samples from the three treatments were analyzed based on 16S rRNA gene sequence data. In total, 1285 OTUs were delineated at the $97 \%$ similarity level of which 1256, 1229, and 1269 OTUs were detected in the ASW, WDW, and nWCW treatments, respectively. Among these OTUs, 1193 were detected in all groups, and only one and two specific OTUs occurred under ASW and nWCW, respectively (Fig. 3A). Among the three weed control methods, no significant difference in the Simpson index was observed ( $p>0.05 ;$ Fig. $3 C$ ). The Shannon and Chao1 indices under WDW were significantly higher than those of the ASW and nWCW treatments $(p<0.05 ;$ Fig. 3B, D). These results showed that the bacterial communities in the ASW and nWCW treatments were more diverse than under WDW.

The correlation coefficients between the bacterial alpha-diversity indices and soil parameters are shown in Table 2. The values for the abundance-based coverage estimator (ACE), Shannon index, and Simpson index were positively correlated with soil pH, moisture content, and AP content $(p<0.05)$, and negatively correlated with $\mathrm{NH}_{4}{ }^{+}-\mathrm{N}, \mathrm{TN}$, and DOC contents $(p<0.05)$.

Table 2

Correlation coefficients (Spearman's $\rho$ ) between the dominant bacterial alpha diversity and soil properties

\begin{tabular}{|c|c|c|c|c|c|c|c|c|}
\hline & $\mathrm{pH}$ & SM & $\mathrm{NH} 4^{+}-\mathrm{N}$ & $\mathrm{NO}^{3-}-\mathrm{N}$ & TN & AP & TP & DOC \\
\hline ACE & 0.481 & 0.340 & -0.572 & -0.334 & -0.529 & 0.419 & -0.210 & -0.215 \\
\hline Chao1 & 0.401 & 0.376 & -0.579 & -0.263 & -0.490 & 0.386 & -0.221 & -0.294 \\
\hline Shannon index & 0.322 & 0.648 & -0.539 & -0.249 & -0.498 & 0.454 & -0.253 & -0.561 \\
\hline Simpson index & 0.170 & 0.622 & -0.3744 & -0.003 & -0.294 & 0.308 & -0.337 & -0.535 \\
\hline OTU number & 0.331 & 0.426 & -0.489 & 0.051 & -0.542 & 0.254 & -0.321 & -0.278 \\
\hline
\end{tabular}

Significant values $(p<0.05)$ are in bold. ACE: Abundance-based coverage estimator; OTU: operational taxonomic unit; SM: soil moisture; TN: total nitrogen; AP: available phosphorus; TP: total phosphorus; DOC: dissolved organic matter

\section{Beta diversity}

Principal coordinate analysis based on a Bray-Curtis distance matrix was used to evaluate the similarity of soil microbiota under the weed control treatments. The first and second principal coordinates explained $55.90 \%$ and $15.40 \%$ of the total variation associated with the differences between weeding methods (Fig. 4A). PERMANOVA analysis based on Bray-Curtis distances revealed that the diversity of soil bacterial communities differed significantly among the weed control methods $\left(R^{2}=0.275, p=0.001\right)$. Significant differences were observed between ASW and WDW $\left(R^{2}=0.207, p=0.001\right)$, ASW and nWCW $\left(R^{2}=0.176, p=0.006\right)$, and between WDW and nWCW $\left(R^{2}=0.265, p=0.001\right)$, which indicated that unique bacterial communities were formed in response to the three weeding methods (Fig. 4A). In addition, hierarchical clustering using the UPGMA algorithm revealed a distinct disparity among the soil bacterial communities under the weeding methods (Fig. 4B). These results indicated that the structure of the soil bacterial communities was more similar between ASW and nWCW compared with that under WDW.

\section{Bacterial diversity}

The diversity of bacterial OTUs was assessed at different taxonomic levels. The predominant bacteria at the phylum level were Proteobacteria, Acidobacteria, Chloroflexi, Actinobacteria, Verrucomicrobia, Firmicutes, Bacteroidetes, Planctomycetes, Gemmatimonadetes, and Saccharibacteria. Among these phyla, Proteobacteria were the most abundant group under ASW and WDW, 
which accounted for $31.3 \%$ and $36.1 \%$ of the total bacterial diversity, respectively. Acidobacteria was the most abundant bacterial phylum under nWCW, which accounted for $36.2 \%$ of the total bacterial diversity (Fig. $5 \mathrm{~A}$ ). At the class level, the ten dominant bacterial taxa comprised $76.8 \%, 79.3 \%$, and $78.0 \%$ of the bacterial communities in the ASW, WDW, and nWCW treatments, respectively. Among the three treatments, Alphaproteobacteria (20.1\%), Gammaproteobacteria (14.3\%), and Subgroup_2 (15.1\%) (all classes of Acidobacteria) were the most abundant classes in the bacterial communities (Fig. 5B). Xanthomonadales, Acidobacteriales, C_Subgroup_2, Rhizobiales, Rhodospirillales, C_JG37-AG-4, Solibacterales, Frankiales, Ktedonobacterales, and Burkholderiales were the most abundant bacterial orders, which in total accounted for $57.0 \%, 62.7 \%$, and $47.2 \%$ of the bacterial diversity in the ASW, WDW, and nWCW treatments, respectively (Fig. 5C). The most abundant bacterial order under WDW was Xanthomonadales, which accounted for $15.9 \%$ of the total bacterial diversity (Fig. 5C). At the family level, Acidobacteriaceae, C_Subgroup_2, C_JG37-AG-4, Solibacteraceae, DA111, Xanthomonadaceae, Acidothermaceae, Sphingomonadaceae, ODP1230B8.23, and Ktedonobacteraceae showed the highest abundance. Of these families, Acidobacteriaceae, Xanthomonadaceae, and c_Subgroup_2 were the most abundant in the three treatments collectively (Fig. 5D). The predominant identifiable genera were c_Subgroup_2, f_Acidobacteriaceae_[Subgroup_1], C_JG37-AG-4, Solibacter, Acidothermus, f_ODP1230B8.23, Sphingomonas, O_Acidimicrobiales, Mucilaginibacter, and Variibacter (Fig. 5E).

Abundance of three bacterial taxonomic groups

A LEfSe analysis of the taxa that were differentially abundant among the ASW, WDW, and nWCW treatments was performed (Fig. 6B). The cladogram revealed distinct differences in 42 taxa among the three treatments with LDA scores $\geq 4.0$ (Fig. 6A). At the genus level, Candidatus_Solibacter were the most abundant in nWCW, and Ktedonobacter, Mucilaginibacter, and Leifsonia were the most abundant in WDW (Fig. 6C). The weed control method variously influenced bacterial composition at the phylum level. The phylum Gemmatimonadetes showed higher relative abundance under ASW compared with that under WDW and nWCW. Abundance of Firmicutes, Bacteroidetes, and Actinobacteria was significantly higher under WDW, and lower in the ASW and nWCW treatments. The relative abundance of Verrucomicrobia and Acidobacteria was higher in the nWCW treatment, but relatively lower under ASW and WDW (Fig. S1). Some taxa at the class, order, family, and species levels were revealed to differ distinctly in abundance among the three treatments (Fig. 6B).

Molecular ecology network analysis of soil bacterial communities

Potential bacteria-bacteria interactions were examined by constructing bacterial co-occurrence networks. Three networks were constructed based on OTU abundance (Fig. 7). Among the three weeding methods, differences in the values of network size, edges, degree, density, clustering coefficient, and modularity were observed (Table 3). With increase in number of nodes and edges, bacterial assemblages were clustered into a larger and more complex network of topological structures in the ASW and nWCW treatments compared with that under WDW, respectively. In addition, the values of average degree, graph density, and clustering coefficient were higher under ASW and nWCW than those under WDW. The modularity under WDW was larger than that of the other two treatments; the nWCW method showed the minimum modularity. However, the modularity in all three groups was higher than 0.4 , which indicated that each weeding method resulted in an effective co-occurrence network. In summary, the co-occurrence networks of soil bacterial communities under ASW and nWCW were most similar and more complex than under WDW.

Table 3

Topological properties of the co-occurrence network in the three weeding treatments.

\begin{tabular}{|llll|}
\hline Topological properties & ASW & WDW & nWCW \\
\hline Nodes & 207 & 197 & 205 \\
\hline Edges & 371 & 308 & 441 \\
\hline Average degree & 3.585 & 3.127 & 4.302 \\
\hline Graph density & 0.017 & 0.016 & 0.021 \\
\hline Clustering coefficient & 0.026 & 0.015 & 0.036 \\
\hline Modularity & 0.524 & 0.589 & 0.453 \\
\hline ASW: Artificial sickle weeding; WDW: woody disc weeding; nWCW: nonwoven cloth weeding \\
\hline
\end{tabular}

Relationship between bacterial community structure and soil properties

Page $7 / 19$ 
The Mantel test revealed that bacterial community structure was strongly correlated with soil properties, comprising soil moisture, $\mathrm{NO}_{3}{ }^{-}-\mathrm{N}, \mathrm{TP}, \mathrm{DOC}, \mathrm{NH}_{4}{ }^{+}-\mathrm{N}$, and $\mathrm{pH}(p<0.05)$. The correlation coefficients showed the following trend: soil moisture $>\mathrm{NO}_{3}{ }^{-} \mathrm{N}>\mathrm{TP}>\mathrm{pH}$ $>\mathrm{DOC}>\mathrm{NH}_{4}{ }^{+}-\mathrm{N}$. The relationship of these soil properties with the dominant bacteria at phylum level was further analyzed using CCA (Fig. 8). The soil variables explained $38.0 \%$ of the bacterial community variation of which the first axis explained $29.6 \%$ and the second $8.4 \%$. The correlations between the ten most abundant bacteria at phylum level and soil properties were analyzed (Table 4). The most dominant phyla were significantly correlated with soil moisture, whereas no bacterial phyla were correlated with $\mathrm{NO}_{3}{ }^{-} \mathrm{N}^{-}$and TP $(p<0.05)$. Gemmatimonadetes and Planctomycetes were positively correlated with $\mathrm{pH}$ and negatively correlated with $\mathrm{NH}_{4}{ }^{+}-\mathrm{N}$, respectively $(p<0.05)$. Gemmatimonadetes and Verrucomicrobia were negatively correlated with TN, whereas Chloroflexi and Gemmatimonadetes were positively and negatively correlated with DOC, respectively $(p<0.05)$. Only Gemmatimonadetes was positively correlated with AP $(p<0.05)$.

Table 4

Spearman's correlation coefficients between soil properties and ten most abundant soil bacterial phyla

\begin{tabular}{|llllllllll|}
\hline & pH & SM & NH4 ${ }^{+}-\mathbf{N}$ & NO $^{3-}-\mathbf{N}$ & TN & AP & TP & DOC \\
\hline Acidobacteria & 0.179 & $\mathbf{0 . 6 5 9}$ & -0.320 & 0.366 & -0.315 & 0.109 & -0.249 & -0.212 \\
\hline Actinobacteria & -0.081 & -0.682 & 0.157 & -0.418 & 0.337 & -0.044 & 0.195 & 0.174 \\
\hline Bacteroidetes & 0.046 & -0.545 & 0.113 & -0.413 & 0.238 & 0.118 & 0.287 & 0.022 \\
\hline Chloroflexi & -0.144 & -0.468 & 0.285 & 0.336 & 0.363 & -0.297 & -0.030 & $\mathbf{0 . 5 5 6}$ \\
\hline Firmicutes & -0.128 & $-\mathbf{0 . 5 3 5}$ & 0.170 & -0.201 & 0.098 & 0.139 & -0.094 & -0.088 \\
\hline Gemmatimonadetes & $\mathbf{0 . 5 1 4}$ & $\mathbf{0 . 4 6 0}$ & $-\mathbf{0 . 5 7 2}$ & -0.582 & -0.663 & $\mathbf{0 . 4 9 8}$ & -0.022 & -0.478 \\
\hline Proteobacteria & -0.280 & -0.331 & 0.288 & -0.312 & 0.098 & -0.032 & 0.201 & -0.075 \\
\hline Saccharibacteria & -0.026 & $-\mathbf{0 . 6 7 5}$ & 0.109 & -0.421 & 0.131 & -0.005 & 0.104 & 0.132 \\
\hline Verrucomicrobia & 0.295 & $\mathbf{0 . 4 8 6}$ & -0.399 & 0.200 & -0.483 & 0.019 & -0.385 & -0.210 \\
\hline Planctomycetes & $\mathbf{0 . 6 1 0}$ & 0.361 & -0.619 & -0.118 & -0.352 & 0.340 & 0.202 & -0.272 \\
\hline
\end{tabular}

Significant values $(p<0.05)$ are in bold. SM: soil moisture; TN: total nitrogen; AP: available phosphorus; TP: total phosphorus; DOC: dissolved organic matter

Prediction of bacterial functional potential and phenotypes

To explore the functional roles of bacteria in the soil of the Chinese fir plantatiton, PICRUSt was used to predict their function based on KEGG metabolic pathways and the relative frequencies of predicted functions in carbon metabolism, nitrogen metabolism, and the phosphorus cycle were analyzed. The functional discrepancy differed significantly among the weed control methods (Fig. 9A). Under nWCW, bacterial metabolic pathways associated with methane metabolism, carbohydrate digestion and absorption, nitrogen metabolism, nitrotoluene degradation, and phosphotransferase system were significantly decreased compared with ASW and WDW $(p \leq 0.05)$. However, pathways concerned with carbon fixation in prokaryotes and oxidative phosphorylation were obviously reduced under WDW compared with ASW and nWCW ( $p \leq 0.05)$.

Based on 16S rRNA gene sequence data, the phenotypic shift of the soil bacterial community was investigated using BugBase. Under WDW, the relative abundance of anaerobic and Gram-negative bacteria was distinctly decreased, whereas the relative abundance of bacteria possessing potential for pathogenic, stress tolerance, and mobile element-containing phenotypes was significantly increased $(p \leq 0.05)$ (Fig. 9B). The relative abundance of other bacterial phenotypic functions, such as aerobic and biofilm forming, did not differ significantly among the three weeding methods. The predictions of bacterial functional and phenotypic potential indicated that, compared with WDW, the relative frequencies and abundance of the bacterial functions and phenotypes were most similar between the ASW and nWCW treatments.

Effects of weeding method on needle nutrient contents 
The sugar content of new needles of Chinese fir seedlings under nWCW were higher than that under MSW and WDW (Fig. 10A). The content of GLU in new needles was significantly higher in nWCW than those in MSW and WDW $(p<0.05$, Fig. 10B). The contents of TG and FFAs in new needles in the WDW treatment were significantly lower than those in new needles under the MSW and nWCW treatments ( $p<0.05$, Fig. 10B, C). The TCH content showed no significant difference among the weed control methods (Fig. 10B). Thus, the weeding methods influenced the soil properties, such as water and $\mathrm{N}$ contents, and the sugar and glucose contents of new needles.

The correlations of bacterial alpha-diversity indices and soil properties with needle nutrient contents are summarized in Table S1. All alpha-diversity indices, comprising OTU number, ACE, Chao1, Simpson, and Shannon indices, showed a significant positive correlation with FFA content in new needles $(p<0.05)$. Soil moisture content was positively correlated with FFA content, and negatively correlated with DOC and TN contents $(p<0.05)$. The soil moisture content significantly contributed to production of sugar and GLU in new needles, whereas the TN content negatively influenced the biosynthesis of TG.

Transcription of genes associated with carbohydrate metabolism in new needles

To examine the change in energy metabolism of newly developed needles, the transcript abundance of genes associated with energy metabolism in new needles was analyzed. The relative mRNA levels of genes associated with glucose metabolism were significantly changed. For example, the transcript level of the glucose kinase gene in new needles under nWCW was significantly higher than that under the other two weeding methods $(p<0.05$, Fig. 11A). Compared with nWCW, the mRNA levels of sucrose phosphate synthase and sucrose synthase genes in new needles was significantly lower under WDW ( $p<0.05$, Fig. 11B, C). In contrast, the mRNA level of the hexokinase gene in the nWCW treatment was significantly lower than that under ASW and WDW $(p<0.05$, Fig. 11D). These results indicated that the carbohydrate metabolism of new needles of Chinese fir was distinctly affected by the different weeding methods.

\section{Discussion}

Effects of weeding method on bacterial community structure

In this study, Proteobacteria, Acidobacteria, Chloroflexi, Actinobacteria, and Verrucomicrobia were the predominant bacterial phyla in the soil of the Chinese fir plantation, which was consistent with previous reports (Liu et al., 2020a; Wang et al., 2018). Acidobacteria are among the most abundant and ubiquitous bacterial phyla in global soil environments (Rawat et al., 2012). These bacteria harbor genes that encode polyketide synthase and nonribosomal peptide synthase, which are well known for their roles in the synthesis of antibiotics and antifungals (Ward et al., 2009). On account of these characteristics, most Acidobacteria populations are beneficial to plant health. Niu et al. (2016) reported that Acidobacteria (including Acidobacteria_Gp6 and Acidobacteria_Gp4) were negatively correlated with tobacco disease, suggesting their possible function in disease suppression. Acidobacteria possess the capability to degrade complex and recalcitrant carbon compounds, including polysaccharides such as cellulose and xylan (Ward et al., 2009; Ai et al., 2015). In the present study, the potential functions of bacteria associated with carbon metabolism, such as carbohydrate digestion and absorption, and glycan degradation were less abundant in the WDW treatment, which may be consistent with the deficiency of Acidobacteria. However, the abundance of Actinobacteria after weeding with the WDW method indicated a relatively rapid growth rate of these organisms because they are indicative of high carbon availability. Actinobacteria exhibit the ability to utilize lignin-derived compounds and consequently are involved in the advanced stage of litter decomposition (Kirby, 2006), which implies that these bacteria can provide adequate nutrients for the growth of Chinese fir. In addition, the abundance of two phyla, Chloroflexi and Firmicutes, is positively correlated with tobacco disease incidence (Niu et al., 2016). In contrast, the abundance of the phyla Acidobacteria, Verrucomicrobia, and Gemmatimonadetes is negatively correlated with frequency of tobacco bacterial wilt (Niu et al., 2016), which may account for the abundance of genes associated with pathogenic potential in the current study.

At the genus level, Candidatus_Solibacter plays an important role in reduction of nitrite and nitrate, which contributes to the $\mathrm{N}$ cycle (Ward et al., 2009). These bacteria have a versatile genome that is adapted to breakdown recalcitrant organic compounds and carbohydrates, and provide a suitable environment for other microbes involved in the degradation of complex organic materials (Rawat et al., 2012; Li et al., 2018). Candidatus_Solibacter are abundant in the rhizosphere of black pepper, Panax notoginseng, and rice, and are positively associated with rice cropping (Lepos et al., 2014; Tan et al., 2017; Umadevi et al., 2018). Ktedonobacteria, members of the Chloroflexi phylum, were also highly abundant. The genus Ktedonobacter is characterized as mesophilic, aerobic, heterotrophic, moderately acidophilic bacteria that are also able to grow in a microaerophilic environment (Cavaletti et al., 2006). Ktedonobacter are linked with tobacco disease because these bacteria are non-nitrogen fixers that may compete with the microbial 
community for a N source (Niu et al., 2016). In the Pinus rhizosphere, Ktedonobacter are postulated to play a critical role in maintaining the microbial community structure (Wang et al., 2018). The genus Mucilaginibacter are heterotrophic bacteria capable of degrading pectin, xylan, laminarin, and other polysaccharides (Pankratov et al., 2007). Madhaiyan et al. (2010) isolated two Mucilaginibacter from the rhizosphere soil of cotton, Mucilaginibacter gossypii sp. nov. and Mucilaginibacter gossypiicola sp. nov., which produce abundant amounts of extracellular polysaccharides and possess plant-growth-promoting traits. The genus Leifsonia comprises Gram-positive, non-spore-forming, and irregular rod- or filament-shaped bacteria that are reported to differ in phenotypic potential. For instance, Leifsonia xyli subsp. xyli, a unique xylem-limited and fastidious bacterial pathogen, is the cause of ratoon stunting disease (Purcell and Hopkins, 1996). These bacteria show obvious antagonistic activity, and can produce indole-3-acetic acid and promote root and shoot height of chili seedlings under an in vivo greenhouse environment (Passari et al., 2015). The present results indicated that after weeding using the WDW method, bacteria equipped with the plant-pathogenic potential were more abundant than under the ASW and nWCW weed control methods.

Correlation between soil bacteria and soil properties

Soil properties, such as $\mathrm{N}$ and $\mathrm{P}$ contents, are critical for plant growth in tropical forest plantations (Chen et al., 2015). Nitrogen is considered to be a limiting factor that influences primary productivity in forest ecosystems, and continued anthropogenic $\mathrm{P}$ additions are essential to improve forest primary production (Cleveland et al., 2006; Weand et al., 2010). Although these nutrients may impact on the abundance, diversity, and community composition of soil microbes, which play an important role in regulating soil fertility, soil microorganisms are important drivers of energy flow and nutrient cycling, such as carbon, $\mathrm{N}$, and $\mathrm{P}$ cycling in terrestrial ecosystems (Artursson et al., 2006; Morris and Blackwood, 2015). Therefore, soil functioning depends primarily on microbial community structure, activity, and stability (Dunbar et al., 2002; Coleman and Whitman, 2005).

In addition, soil microorganisms are sensitive to changes in soil nutrients and $\mathrm{pH}$. Soil bacterial communities can be a potential ecological indicator of soil quality. The input of $\mathrm{N}$ was previously believed to reduce microbial abundance and biodiversity (He et al., 2007; Geisseler et al., 2014; Zhou et al., 2015; Wang et al., 2017; Nie et al., 2018). In the present study, the number of 16S rRNA-based OTUs and alpha diversity were closely associated with $\mathrm{NH}_{4}{ }^{+}-\mathrm{N}$ and TN contents, rather than AP and TP contents, which further confirms the importance of $\mathrm{N}$ in altering bacterial diversity. In addition, the results of recent studies support the contention that inorganic P does not affect bacterial diversity (Huang et al., 2016; Liu et al., 2018). The present results suggested that inorganic $P$ may not be a limiting factor that affected bacterial biodiversity in the Chinese fir plantation. Moreover, a bacterial community is significantly influenced by soil $\mathrm{pH}$ because most bacterial taxa show relatively narrow growth tolerances, especially within the $\mathrm{pH}$ range of 4-7 (Dai et al., 2018; Rousk et al., 2010). However, in the current study, pH was not a decisive factor that affected bacterial diversity, whereas soil moisture content had a significantly positive effect. Li et al. (2021) reported that soil moisture content significantly improves plant productivity, and soil bacterial abundance and diversity in the wheat root zone. In amended soils, bacterial diversity, richness, and community composition at $25 \%$ of the water-holding capacity distinctly differs from those at $55 \%$ of the water-holding capacity (Chen et al., 2015). We observed that the DOC content showed a significant negative correlation with bacterial diversity, which is consistent with the results of previous studies (Tian et al., 2018; Wang et al., 2018).

Different responses of major phyla to soil parameters, such as inorganic $\mathrm{N}$ and $\mathrm{P}$ contents, might be one reason for the change in bacterial diversity. The present study revealed that Gemmatimonadetes were negatively correlated with $\mathrm{NH}_{4}{ }^{+}-\mathrm{N}, \mathrm{NO}_{3}{ }^{-}-\mathrm{N}$, and TN contents, and Verrucomicrobia were negatively correlated with TN content. These findings are supported by a long-term fertilization experiment in which the relative abundances of Acidobacteria, Gemmatimonadetes, and Verrucomicrobia declined with $\mathrm{N}$ fertilization (Cederlund et al., 2014). However, the AP and TP contents did not affect the relative abundance of the dominant phyla, which may be because the soil available P content was less than $100 \mathrm{mg} \mathrm{kg}^{-1}$ and soil-borne copiotrophic bacteria are not dominant (Kuramae et al., 2011). On the basis of Spearman's correlation analysis, soil moisture content was significantly correlated with the majority of bacterial phyla, which was supported by the results of a Mantel test and CCA analysis. These results implied that soil moisture content was a more important factor than other soil properties in shaping the bacterial community structure.

\section{Conclusion}

Our results suggested that three non-chemical weed control methods had different effects on soil physicochemical properties, soil bacterial community structure, nutrient status of newly developed needles, expression in the needle of selected genes associated with energy metabolism, and growth of Chinese fir seedlings. soil properties were closely correlated with bacterial diversity, and nutrient

Page $10 / 19$ 
contents of new leaves. Soil moisture was clearly connected with the dominated bacteria at phyla level, and bacterial diversity had a significantly positive effects on the biosynthesis of free fatty acids in seedlings.

\section{Declarations}

\section{Acknowledgements}

This work was financially supported by the National Key Research and Development Program of China (grant no. 2016YFD06003022). We thank Xiangying Jiang and Wenliang Zhao for their help for our project. We thank Robert McKenzie, PhD, from Liwen Bianji (Edanz) (www.liwenbianji.cn/) for editing the English text of a draft of this manuscript.

\section{Declaration of interests}

The authors declare that they have no known competing financial interests or personal relationships that could have appeared to influence the work reported in this paper.

\section{References}

1. Ai C, Liang G, Sun J, Wang X, He P, Zhou W, He X (2015) Reduced dependence of rhizosphere microbiome on plant-derived carbon in 32-year long-term inorganic and organic fertilized soils. Soil Biol Biochem 80: 70-78. https://doi:

10.1016/j.soilbio.2014.09.028

2. Allen SE, Grimshaw HM, Parkinson JA, Quarmby C (1974) Chemical analysis of ecological materials. Blackwell Scientific Publications

3. Artursson V, Finlay RD, Jansson JK (2006) Interactions between arbuscular mycorrhizal fungi and bacteria and their potential for stimulating plant growth. Environ Microbiol 8: 1-10. https://doi.org/10.1111/j.1462-2920.2005.00942.x

4. Bajwa AA, Mahajan G, Chauhan BS (2015) Nonconventional weed management strategies for modern agriculture. Weed science 63(4): 723-747. https://doi.org/10.1614/WS-D-15-00064.1

5. Bi J, Blanco JA, Seely B, Kimmins JP, Ding Y, Welham C (2007) Yield decline in Chinese-fir plantations: a simulation investigation with implications for model complexity. Can J For Res 37(9):1615-1630. https://doi.org/10.1139/X07-018

6. Caporaso JG, Kuczynski J, Stombaugh J, Bittinger K, Bushman FD, Costello EK, Knight R (2010) QIIME allows analysis of highthroughput community sequencing data. Nat Methods 7:335-336. https://doi.org/10.1038/nmeth.f.303

7. Cavaletti L, Monciardini P, Bamonte R, Schumann P, Rohde M, Sosio M, Donadio S (2006) New lineage of filamentous, sporeforming, gram-positive bacteria from soil. App Environ Microb 72:4360-4369. https://doi.org/10.1128/AEM.00132-06

8. Cederlund H, Wessén E, Enwall K, Jones CM, Juhanson J, Pell M, Hallin S (2014) Soil carbon quality and nitrogen fertilization structure bacterial communities with predictable responses of major bacterial phyla. Appl Soil Ecol 84:62-68. https://doi.org/10.1016/j.apsoil.2014.06.003

9. Chen FS, Niklas KJ, Liu Y, Fang XM, Wan SZ, Wang HM (2015) Nitrogen and phosphorus additions alter nutrient dynamics but not resorption efficiencies of Chinese fir leaves and twigs differing in age. Tree Physiol 35:1106-1117. https://doi.org/10.1093/treephys/tpv076

10. Chen L, Zhang J, Zhao B, Zhou G, Ruan L (2015) Bacterial community structure in maize stubble-amended soils with different moisture levels estimated by bar-coded pyrosequencing. Appl Soil Ecol 86:62-70. https://doi.org/10.1016/j.apsoil.2014.09.011

11. Cierjacks A, Pommeranz M, Schulz K, Almeida-Cortez J (2016) Is crop yield related to weed species diversity and biomass in coconut and banana fields of northeastern Brazil? Agr Ecosyst Enviro 220:175-183. https://doi.org/10.1016/j.agee.2016.01.006

12. Cleveland CC, Reed SC, Townsend AR (2006) Nutrient regulation of organic matter decomposition in a tropical rain forest. Ecology 87:492-503. https://doi.org/10.1890/05-0525

13. Coleman DC, Whitman WB (2005) Linking species richness, biodiversity and ecosystem function in soil systems. Pedobiologia 49(6): 479-497. https://doi.org/10.1016/j.pedobi.2005.05.006

14. Dai Z, Su W, Chen H, Barberán A, Zhao H, Yu M, Xu J (2018) Long-term nitrogen fertilization decreases bacterial diversity and favors the growth of Actinobacteria and Proteobacteria in agro-ecosystems across the globe. Global change biol 24(5):34523461. https://doi.org/10.1111/gcb.14163

Page $11 / 19$ 
15. dos Santos TA, de Resende AS, da Silva FF, Machado AFL, Chaer GM (2019) Weed interference factor that affect the growth on an Atlantic Forest tree species. Embrapa Agrobiologia-Artigo em periódico indexado (ALICE). http://dx.doi.org/10.14393/BJv35n2a2019-41820

16. Du P, He H, Wu X, Xu J, Dong F, Liu X, Zheng Y (2021) Mesosulfuron-methyl influenced biodegradability potential and N transformation of soil. J Hazard Mater 416:125770. https://doi.org/10.1016/j.jhazmat.2021.125770

17. Dunbar J, Barns SM, Ticknor LO, Kuske CR (2002) Empirical and theoretical bacterial diversity in four Arizona soils. App Environ Microb 68: 3035-3045. https://doi.org/10.1128/AEM.68.6.3035-3045.2002

18. Geisseler D, Scow KM (2014) Long-term effects of mineral fertilizers on soil microorganisms-A review. Soil Biol Biochem 75:5463. https://doi.org/10.1016/j.soilbio.2014.03.023

19. Hamberg L, Malmivaara-Lämsä M, Löfström I, Vartiamäki H, Valkonen S, Hantula J (2011) Sprouting of Populus tremula L. in spruce regeneration areas following alternative treatments. Eur J forest Res 130(1):99-106. https://doi.org/10.1007/s10342010-0372-5

20. Harper GJ, Comeau PG, Biring BS (2005) A comparison of herbicide and mulch mat treatments for reducing grass, herb, and shrub competition in the BC interior Douglas-fir zone-ten-year results. West J Appl For 20(3): 167-176. https://doi.org/10.1093/wjaf/20.3.167

21. He JZ, Shen JP, Zhang LM, Zhu YG, Zheng YM, Xu MG, Di H (2007) Quantitative analyses of the abundance and composition of ammonia-oxidizing bacteria and ammonia-oxidizing archaea of a Chinese upland red soil under long-term fertilization practices. Environ microbiol 9: 2364-2374. https://doi.org/10.1111/j.1462-2920.2007.01358.x

22. Hill E (2018) Status of herbicide-resistant weeds in Michigan. Michigan State University Extension Article. online: https://www.canr.msu.edu/news/2018_status_of_herbicide_resistant_weeds_in_michigan

23. Huang J, Hu B, Qi K, Chen W, Pang X, Bao W, Tian G (2016) Effects of phosphorus addition on soil microbial biomass and community composition in a subalpine spruce plantation. Eur J Soil Biol 72: 35-41. https://doi.org/10.1016/j.ejsobi.2015.12.007

24. Weand MP, Arthur MA, Lovett GM, McCulley RL, Weathers KC (2010) Effects of tree species and N additions on forest floor

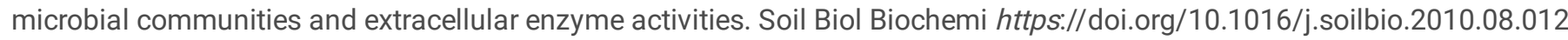

25. Kinney CA, Mandernack KW, Mosier AR (2005) Laboratory investigations into the effects of the pesticides mancozeb, chlorothalonil, and prosulfuron on nitrous oxide and nitric oxide production in fertilized soil. Soil Biol Biochemi 37(5):837-850. https://doi.org/10.1016/j.soilbio.2004.07.044

26. Kirby R (2006) Actinomycetes and lignin degradation. Adv Appl Microbiol 58:125-168. https://doi.org/10.1016/S0065-2164(05)

27. Knowe SA, Stein WI (1995) Predicting the effects of site preparation and protection on development of young Douglas-fir plantations. Can J Forest Res 25(9):1538-1547. https://doi.org/10.1139/x95-167

28. Kuramae E, Gamper H, van Veen J, Kowalchuk G (2011) Soil and plant factors driving the community of soil-borne microorganisms across chronosequences of secondary succession of chalk grasslands with a neutral pH. FEMS Microbiol Ecol 77: 285-294. https://doi.org/10.1111/j.1574-6941.2011.01110.x

29. Li G, Niu W, Sun J, Zhang W, Zhang E, Wang J (2021) Soil moisture and nitrogen content influence wheat yield through their effects on the root system and soil bacterial diversity under drip irrigation. Land Degrad Dev https://doi.org/10.1002/ldr.3967

30. Li Q, Liu C, Wang X, Jin Z, Song A, Liang Y, Müller WE (2018) Influence of altered microbes on soil organic carbon availability in karst agricultural soils contaminated by Pb-Zn tailings. Front Microbiol 9: 2062. https://doi.org/10.3389/fmicb.2018.02062

31. Liu M, Liu J, Chen X, Jiang C, Wu M, Li Z (2018) Shifts in bacterial and fungal diversity in a paddy soil faced with phosphorus surplus. Biol Fert Soils 54(2):259-267. https://doi.org/10.1007/s00374-017-1258-1

32. Liu X, Wang Y, Liu Y, Chen H, Hu Y (2020a) Response of bacterial and fungal soil communities to Chinese Fir (Cunninghamia lanceolate) long-term monoculture plantations. Front Microbiol 11:181. https://doi.org/10.3389/fmicb.2020.00181

33. Liu Y, Fan X, Zhang T, He W, Song F (2020b) Effects of the long-term application of atrazine on soil enzyme activity and bacterial community structure in farmlands in China. Environ Pollu 262: 114264. https://doi.org/10.1016/j.envpol.2020.114264

34. Ma X, Heal KV, Liu A, Jarvis PG (2007) Nutrient cycling and distribution in different-aged plantations of Chinese fir in southern China. Forest Ecol Manag 243(1):61-74. https://doi.org/10.1016/j.foreco.2007.02.018 
35. Madhaiyan M, Poonguzhali S, Lee JS, Senthilkumar M, Lee KC, Sundaram S (2010) Mucilaginibacter gossypii sp. nov. and Mucilaginibacter gossypiicola sp. nov., plant-growth-promoting bacteria isolated from cotton rhizosphere soils. Int J Syst Evol Micro 60:2451-2457. https://doi.org/10.1099/ijs.0.018713-0

36. Mahía J, Cabaneiro A, Carballas T, Díaz-Raviña M (2008) Microbial biomass and C mineralization in agricultural soils as affected by atrazine addition. Biology and Fertility of Soils, 45(1), 99-105. https://doi.org/10.1007/s00374-008-0318-y

37. Morris SJ, Blackwood CB (2015) "The ecology of the soil biota and their function," in Soil Microbiology, Ecology and Biochemistry, 4th Edn, Chap. 10, ed. E. A. Eldor (Cambridge, MA: Academic Press), 273-309. https://dx.doi.org/10.1016/B978-012-415955-6.00010-4

38. Newton M (2006) Taking charge in forest vegetation management. Can J Forest Res 36(10):2357-2363. https://doi.org/10.1139/x06-089

39. Nie Y, Wang M, Zhang W, Ni Z, Hashidoko Y, Shen W (2018) Ammonium nitrogen content is a dominant predictor of bacterial community composition in an acidic forest soil with exogenous nitrogen enrichment. Sci Total Environ 624:407-415. https://doi.org/10.1016/j.scitotenv.2017.12.142

40. Nilsson U, Örlander G (1999) Vegetation management on grass-dominated clearcuts planted with Norway spruce in southern Sweden. Can J Forest Res 29(7):1015-1026. https://doi.org/10.1139/x99-071

41. Niu J, Rang Z, Zhang C, Chen W, Tian F, Yin H, Dai L (2016) The succession pattern of soil microbial communities and its relationship with tobacco bacterial wilt. BMC microbiol 16(1): 1-10. https://doi.org/10.1186/s12866-016-0845- $x$

42. Pankratov TA, Tindall BJ, Liesack W, Dedysh SN (2007) Mucilaginibacter paludis gen. nov., sp. nov. and Mucilaginibacter gracilis sp. nov., pectin-, xylan-and laminarin-degrading members of the family Sphingobacteriaceae from acidic Sphagnum peat bog. Int J Syst Evol Micro 57:2349-2354. https://doi.org/10.1099/ijs.0.65100-0

43. Passari AK, Mishra VK, Gupta VK, Yadav MK, Saikia R, Singh BP (2015) In vitro and in vivo plant growth promoting activities and DNA fingerprinting of antagonistic endophytic actinomycetes associates with medicinal plants. PLoS ONE 10:e0139468. https://doi.org/10.1371/journal.pone.0139468

44. Peachey RE, Landgren CG, Miller TW (2017) Weed and vegetation management strategies in Christmas trees. Oregon State University

45. Purcell AH, Hopkins DL (1996) Fastidious xylem-limited bacterial plant pathogens. Ann Rev P hytopathol 34(1):131-151. https://doi.org/10.1146/annurev.phyto.34.1.131

46. Rawat SR, Männistö MK, Bromberg Y, Häggblom MM (2012) Comparative genomic and physiological analysis provides insights into the role of Acidobacteria in organic carbon utilization in Arctic tundra soils. FEMS Microbiol Ecol, 82: 341-355. https://doi.org/10.1111/j.1574-6941.2012.01381.x

47. Rousk J, Bååth E, Brookes PC, Lauber CL, Lozupone C, Caporaso JG (2010) Soil bacterial and fungal communities across a pH gradient in an arable soil. ISME J 4:1340-1351. https://doi.org/10.1038/ismej.2010.58

48. Sannino F, Gianfreda L (2001) Pesticide influence on soil enzymatic activities. Chemosphere 45:417-425. https://doi.org/10.1016/S0045-6535(01)

49. Santos A, Flores M (1995) Effects of glyphosate on nitrogen fixation of free-living heterotrophic bacteria. Lett Appl Microbiol 20(6): 349-352. https://doi.org/10.1111/j.1472-765X.1995.tb01318.x

50. Schloss PD, Westcott SL, Ryabin T, Hall JR, Hartmann M, Hollister EB, Weber CF (2009) Introducing mothur: open-source, platformindependent, community-supported software for describing and comparing microbial communities. Appl Environ Microbiol 75:7537-7541. https://doi.org/10.1128/AEM.01541-09

51. Schneider WG, Knowe SA, Harrington TB (1998) Predicting survival of planted Douglas-fir and ponderosa pine seedlings on dry, low-elevation sites in southwestern Oregon. New forests 15(2): 139-159. https://doi.org/10.1023/A:1006523404870

52. Segata N, Izard J, Waldron L, Gevers D, Miropolsky L, Garrett WS, Huttenhower C (2011) Metagenomic biomarker discovery and explanation. Genome Biol 12: R60. https://doi.org/10.1186/gb-2011-12-6-r60

53. Seghers D, Verthé K, Reheul D, Bulcke R, Siciliano SD, Verstraete W, Top EM (2003) Effect of long-term herbicide applications on the bacterial community structure and function in an agricultural soil. FEMS Microbiol Ecol 46:139-146.

https://doi.org/10.1016/S0168-6496(03)00205-8 
54. Tan Y, Cui Y, Li H, Kuang A, Li X, Wei Y, Ji X (2017) Diversity and composition of rhizospheric soil and root endogenous bacteria in Panax notoginseng during continuous cropping practices. J Basic Microb 57:337-344.

https://doi.org/10.1002/jobm.201600464

55. Tian D, Xiang W, Chen X, Yan W, Fang X, Kang W, Peng Y (2011) A long-term evaluation of biomass production in first and second rotations of Chinese fir plantations at the same site. Forestry 84(4):411-418. https://doi.org/10.1093/forestry/cpr029

56. Tian J, He N, Hale L, Niu S, Yu G, Liu Y, Zhou J (2018) Soil organic matter availability and climate drive latitudinal patterns in bacterial diversity from tropical to cold temperate forests. Funct Ecol 32(1):61-70. https://doi.org/10.1111/1365-2435.12952

57. Umadevi P, Anandaraj M, Srivastav V, Benjamin S (2017) Trichoderma harzianum MTCC 5179 impacts the population and functional dynamics of microbial community in the rhizosphere of black pepper (Piper nigrum L). Braz J Microbiol 49: 463-470. https://doi.org/10.1016/j.bjm.2017.05.011

58. Vogel JG, Suau LJ, Martin TA, Jokela EJ (2011) Long-term effects of weed control and fertilization on the carbon and nitrogen pools of a slash and loblolly pine forest in north-central Florida. Can J For Res 41(3):552-567. https://doi.org/10.1139/X10-234

59. Wang C, Zheng M, Song W, Wen S, Wang B, Zhu C, Shen R (2017) Impact of 25 years of inorganic fertilization on diazotrophic abundance and community structure in an acidic soil in southern China. Soil Biol Biochem 113:240-249.

https://doi.org/10.1016/j.soilbio.2017.06.019

60. Wang Q, Garrity GM, Tiedje JM, Cole JR (2007) Naive Bayesian classifier for rapid assignment of rRNA sequences into the new bacterial taxonomy. Appl Environ Microb 73:5261-5267. https://doi.org/10.1128/AEM.00062-07

61. Wang Q, Wang C, Yu WW, Turak A, Chen DW, Huang Y, Ao J, Jiang Y, Huang Z (2018) Effects of nitrogen and phosphorus inputs on soil bacterial abundance, diversity, and community composition in Chinese fir plantations. Front Microbiol 9:1543. https://doi.org/10.3389/fmicb.2018.01543

62. Ward NL, Challacombe JF, Janssen PH, Henrissat B, Coutinho PM, Wu M, Kuske CR (2009) Three genomes from the phylum Acidobacteria provide insights into the lifestyles of these microorganism in soils. Appl Environ Microbiol 75:2046-2056. https://doi.org/10.1128/AEM.02294-08

63. Watkins KL, Veum TL, Krause GF (1987) Total nitrogen determination of various sample types: A comparison of the Hach, Kjeltec, and Kjeldahl methods. Journal of the Association of Official Analytical Chemists 70: 410-412. https://doi.org/10.1093/jaoac/70.3.410

64. Zhou J, Jiang X, Wei D, Zhao B, Ma M, Chen S, Li J (2017) Consistent effects of nitrogen fertilization on soil bacterial communities in black soils for two crop seasons in China. Scientific reports 7(1): 1-10. https://doi.org/10.1038/s41598-01703539-6

65. Zimdahl RL (2007) Fundamentals of Weed Science. Academic Press, Elsevier, London

\section{Figures}


ASW

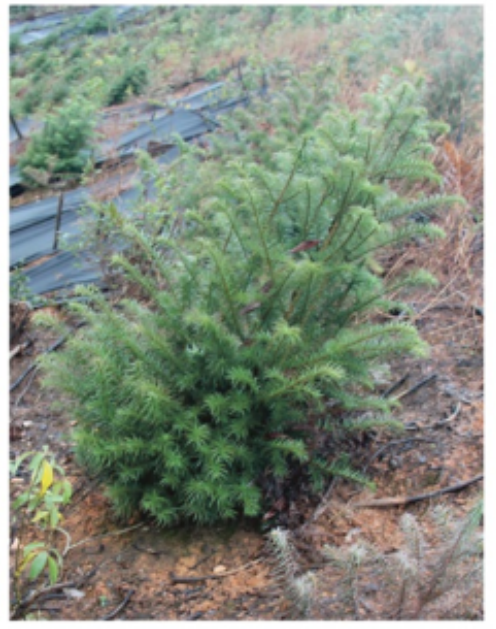

WDW

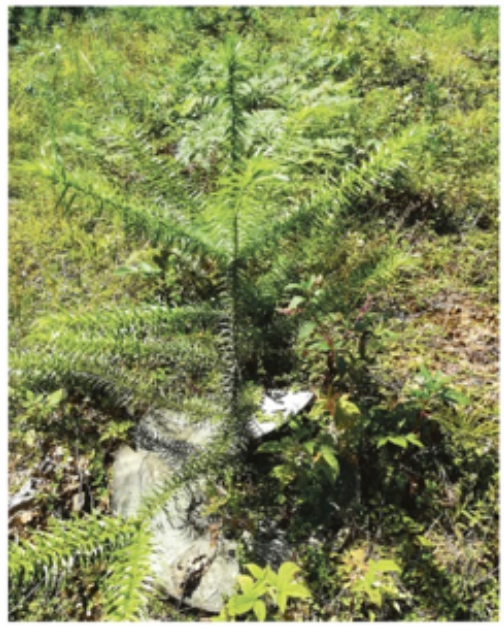

nWCW

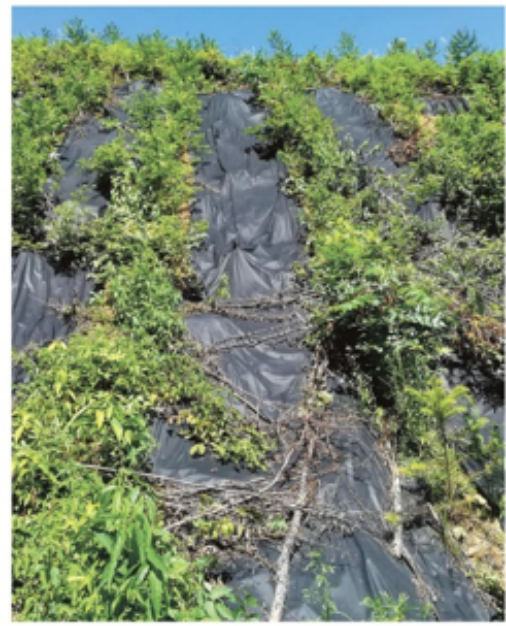

Three different competitive vegetation control methods

\section{Figure 1}

The weed control methods used in this study. ASW: Artificial sickle weeding; WDW: woody disc weeding; nWCW: nonwoven cloth weeding
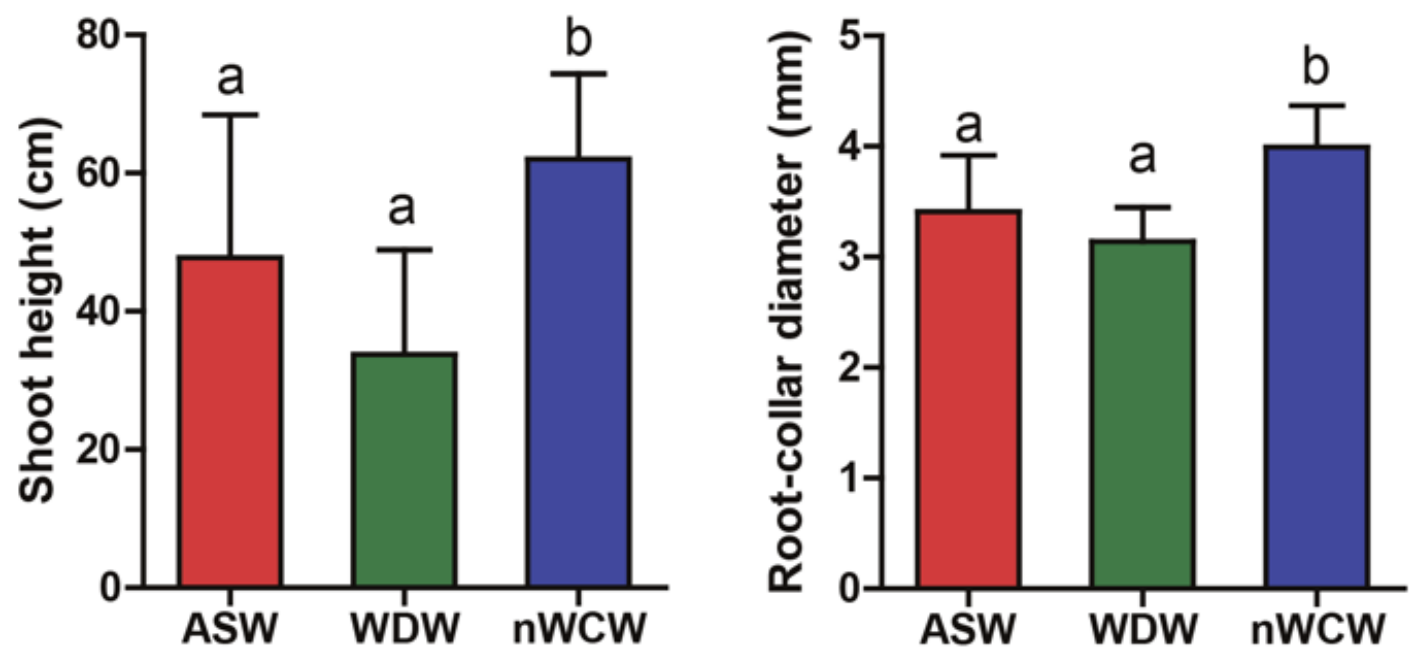

Figure 2

Effect of weed control methods on growth of Chinese fir seedlings. (a) shoot height; (b) root-collar diameter. Different lower-case letters above bars indicate a significant difference between treatments $(p<0.05)$. Values are the mean \pm standard error of the mean. ASW: Artificial sickle weeding; WDW: woody disc weeding; nWCW: nonwoven cloth weeding 
a

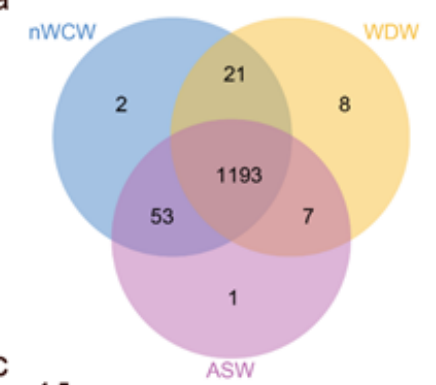

b
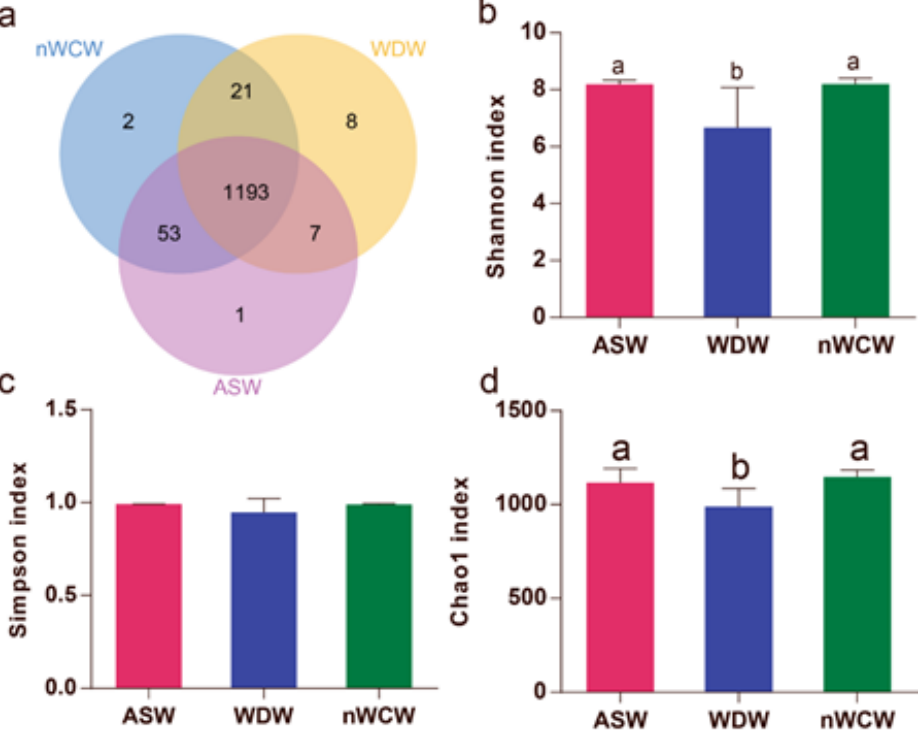

Figure 3

Structure of soil bacterial communities in each weed control treatment. (a) Venn diagram of soil bacterial operational taxonomic units; (b) Shannon index for each weed control method group; (c) Simpson index for each weed control method group; (d) Chao1 index for each weed control method group. ASW: Artificial sickle weeding; WDW: woody disc weeding; nWCW: nonwoven cloth weeding
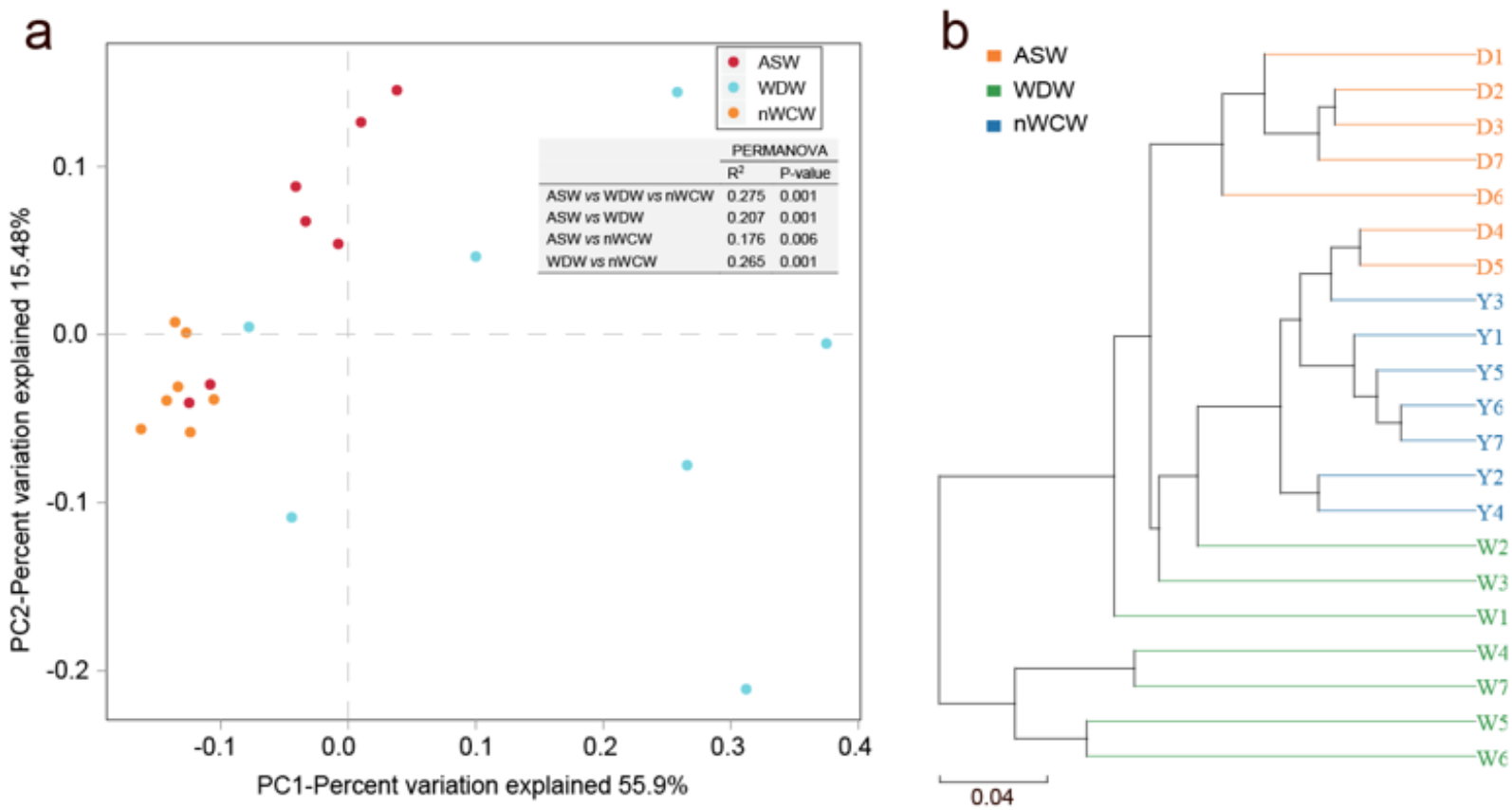

\section{Figure 4}

Beta diversity of soil bacterial communities in the weeding treatment groups. (a) Principal coordinate analysis of Bray-Curtis distance matrix. The percentage of variation explained by each principal coordinate is indicated on the axes. Permutational multivariate analysis of variance (PERMANOVA) quantified the relative similarity of the microbiota among the three groups and between two groups. (b) UPGMA dendrogram based on Bray-Curtis dissimilarity matrix. ASW: Artificial sickle weeding; WDW: woody disc weeding; nWCW: nonwoven cloth weeding 
a

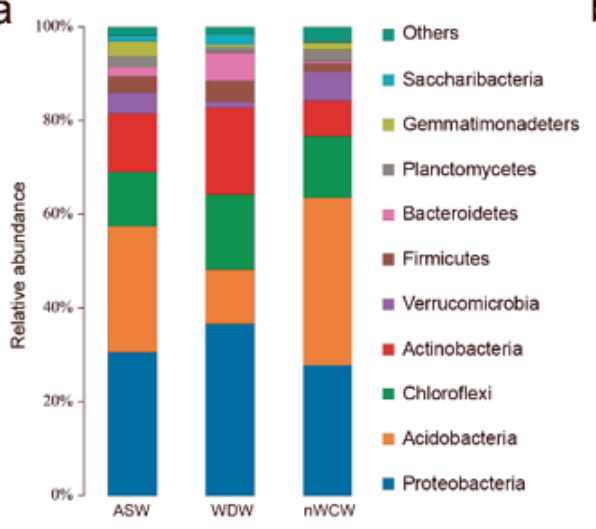

b

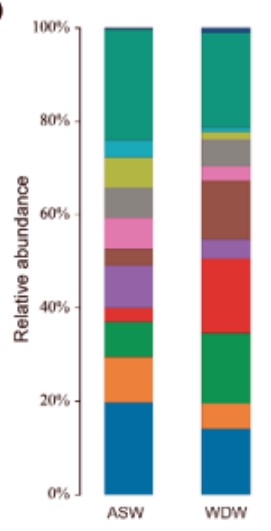

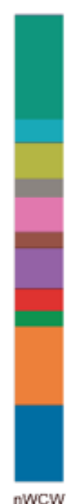

- Unclassified

athers

- Spartobactería

- Solibacteres

- Betaproteobacteria

= JG37-AG-4

- Ktedonobacteria

- Acidobacteria

- Gammaproteobacteria

- Actinobacteria

= Subgroup_2

- Alphaproteobacteria

e

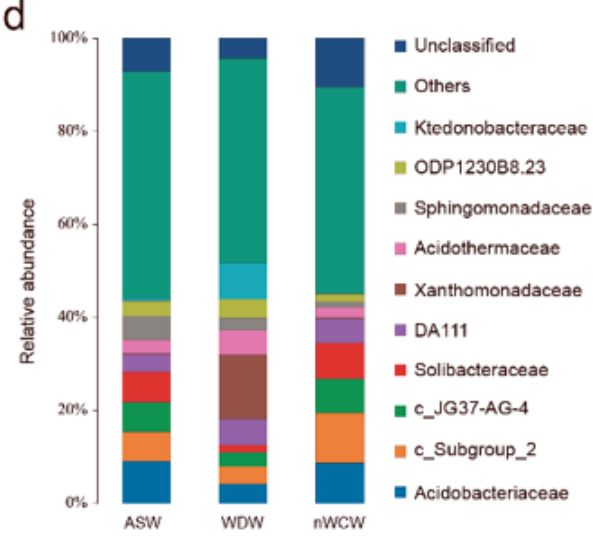

\section{C}

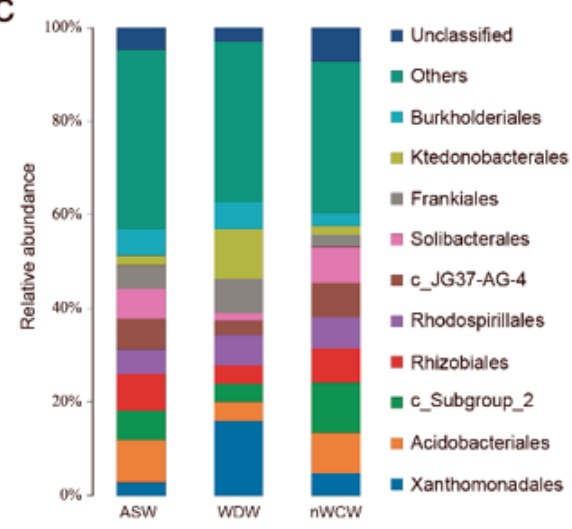

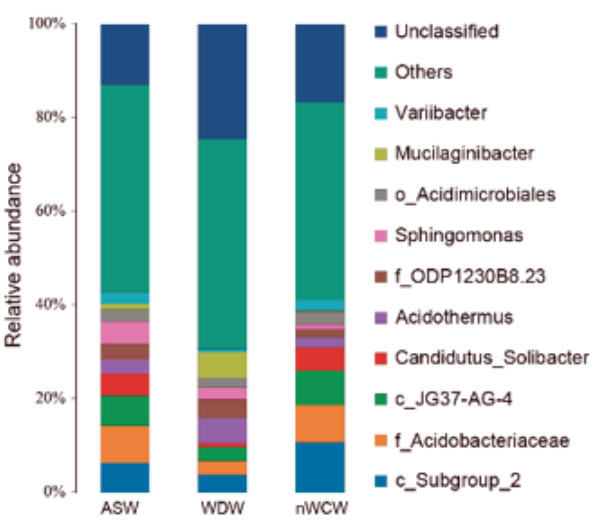

Figure 5

Abundance of soil bacterial communities among the top 10 taxa classified to (a) phylum, (b) class, (c) order, (d) family, and (e) genus. ASW: Artificial sickle weeding; WDW: woody disc weeding; nWCW: nonwoven cloth weeding

\section{Figure 6}

Linear discriminant analysis (LDA) effect size (LEfSe) analysis of bacterial

taxa containing biomarker bacteria at different taxonomic levels. (a) Cladogram indicating the phylogenetic distribution of soil bacterial communities among the three treatment groups. (b) LDA scores showing the bacteria that differed significantly among the three treatment groups (LDA $\geq 4.0$ ). (c) Relative abundance of soil bacteria at genus level (Candidatus Solibacter, Ktedonobacter, Mucilaginibacter, and Leifsonia) in the three treatment groups

\section{Figure 7}

Co-occurrence networks of microbial communities based on Pearson correlation analysis. A connection indicates a strong (Pearson's $r>0.8)$ and significant $(p<0.05)$ correlation. Different colors reflect taxonomic assignment of the operational taxonomic units. The size of each node is proportional to relative abundance. ASW: Artificial sickle weeding; WDW: woody disc weeding; nWCW: nonwoven cloth weeding 


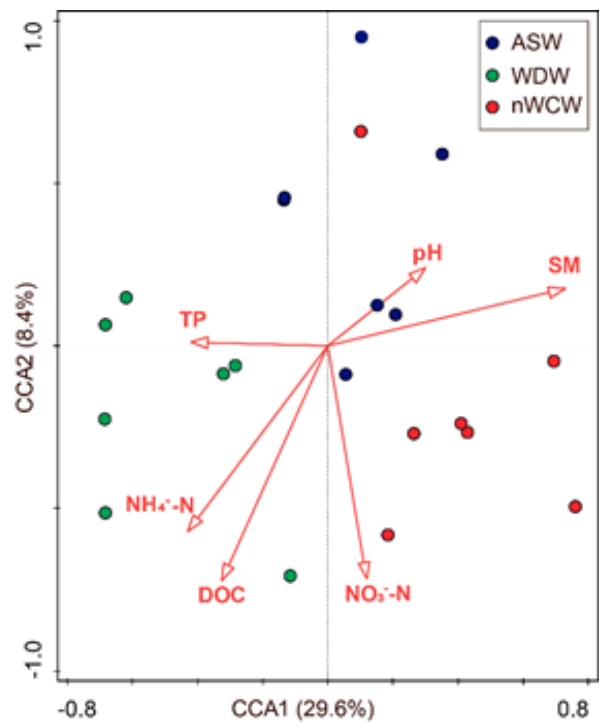

Figure 8

Canonical correspondence analysis (CCA) scatterplot representing the effects of soil properties on bacterial community structure. ASW: Artificial sickle weeding; WDW: woody disc weeding; nWCW: nonwoven cloth weeding; SM: soil moisture; TP: total phosphorus; DOC: dissolved organic matter

\section{Figure 9}

Predicted bacterial functions, functional potential, and phenotypes. (a) Relative frequencies of functional genes of bacteria predicted using PICRUST based on KEGG pathways associated with carbon metabolism (red), nitrogen metabolism (gray), and phosphorus cycle (purple). (b) Bugbase predictions of the organism level of microbiome phenotypes. A significant difference in relative frequencies of functional pathways, functional potential, and phenotypes between two groups were false discovery rate-corrected and is represented by an asterisk $(p \leq 0.05)$. ASW: Artificial sickle weeding; WDW: woody disc weeding; nWCW: nonwoven cloth weeding

\section{Figure 10}

Effects of different weed control methods on nutrient contents of newly developed leaves of Chinese fir seedlings. (a) Sugar content; (b) glucose (GLU), triglyceride (TG), and total cholesterol (TCH) contents; (c) free fatty acid (FFA) content. Different lower-case letters above bars indicate a significant difference between two treatment groups $(p<0.05)$. Values are the mean \pm standard error of the mean. ASW: Artificial sickle weeding; WDW: woody disc weeding; nWCW: nonwoven cloth weeding 

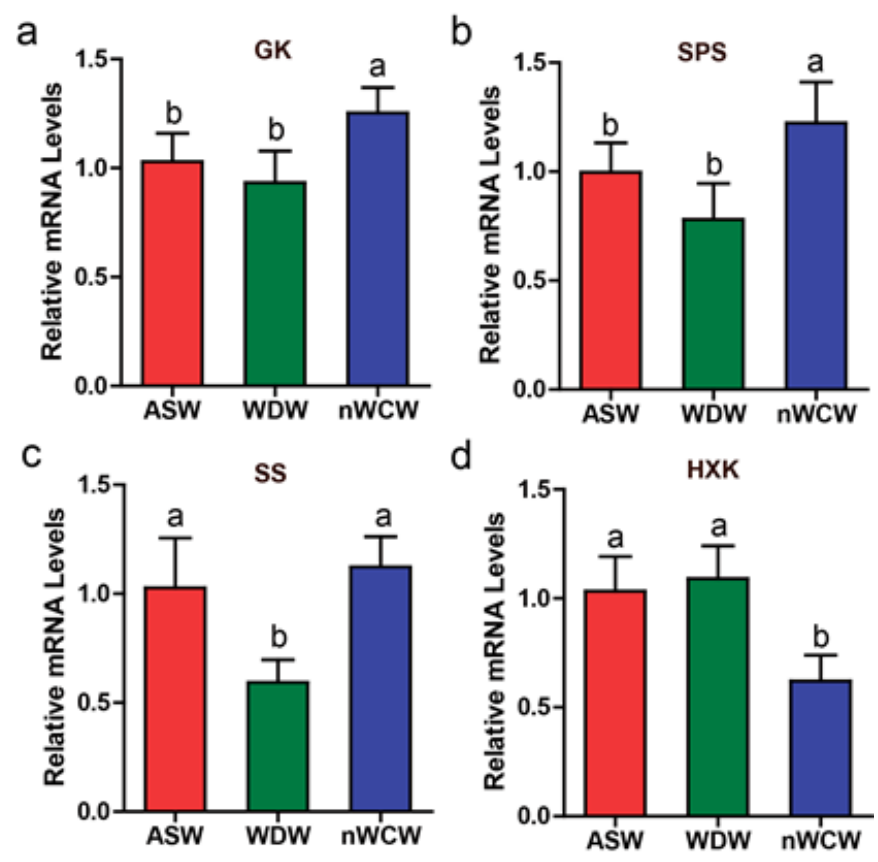

\section{Figure 11}

Effects of different weeding methods on the transcription of genes associated with energy metabolism of newly developed leaves of Chinese fir seedlings. Relative expression of genes relative to the housekeeping gene GAPDH were estimated by RT-qPCR analysis. (a) Glucokinase (GK); (b) sucrose phosphate synthase (SPS); (c) sucrose synthase (SS); (d) hexokinase (HXK). Different lower-case letters above bars indicate a significant difference between two treatment groups $(p<0.05)$. Values are the mean \pm standard error of the mean. ASW: Artificial sickle weeding; WDW: woody disc weeding; nWCW: nonwoven cloth weeding

\section{Supplementary Files}

This is a list of supplementary files associated with this preprint. Click to download.

- supplementarymaterial.docx 